Amaliyah
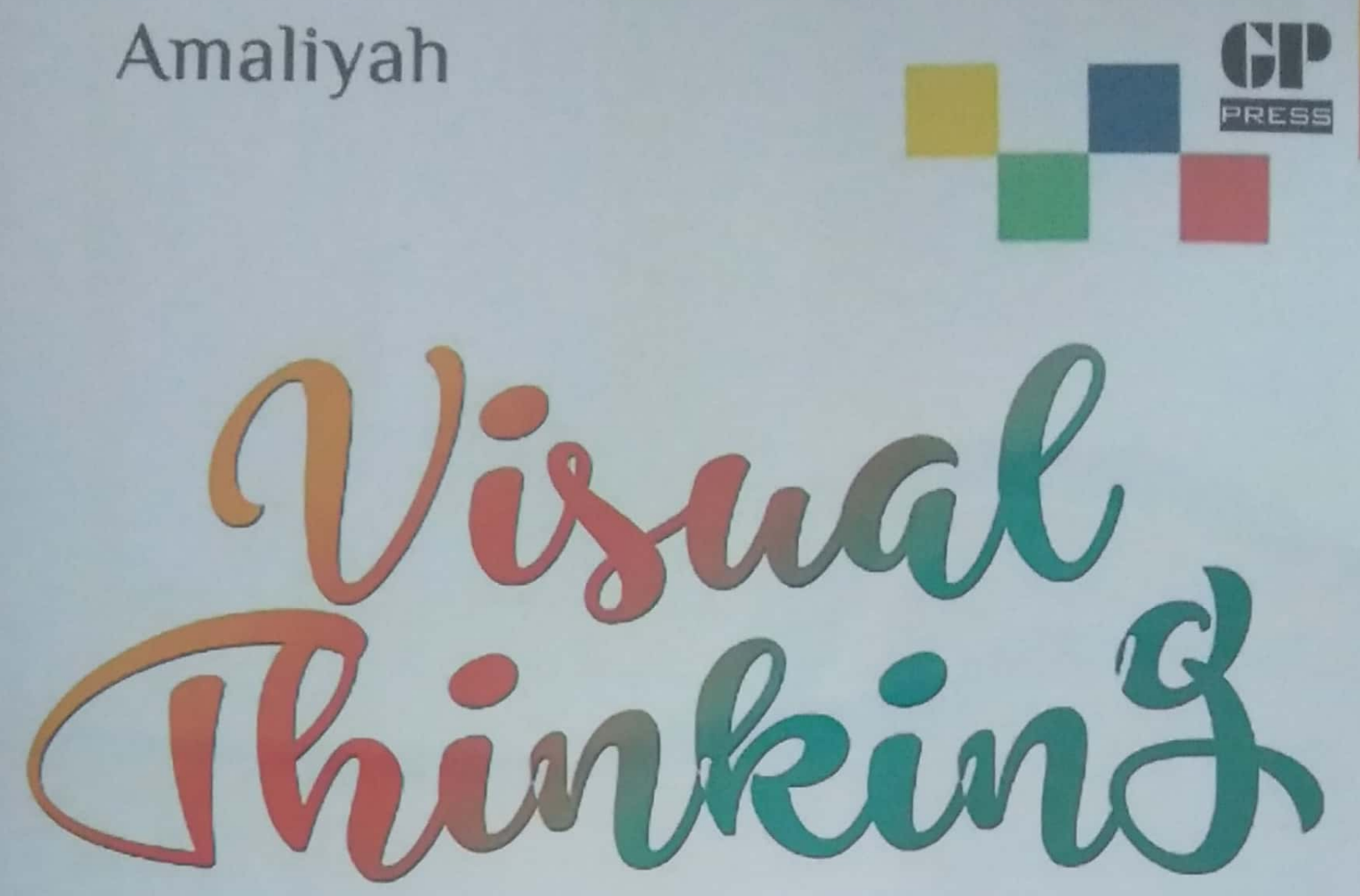

\title{
SISWA TUNARUNGU DALAM PEMBELAJARAN PENDIDIKAN AGAMA ISLAM PADA KELAS INKLUSI
}

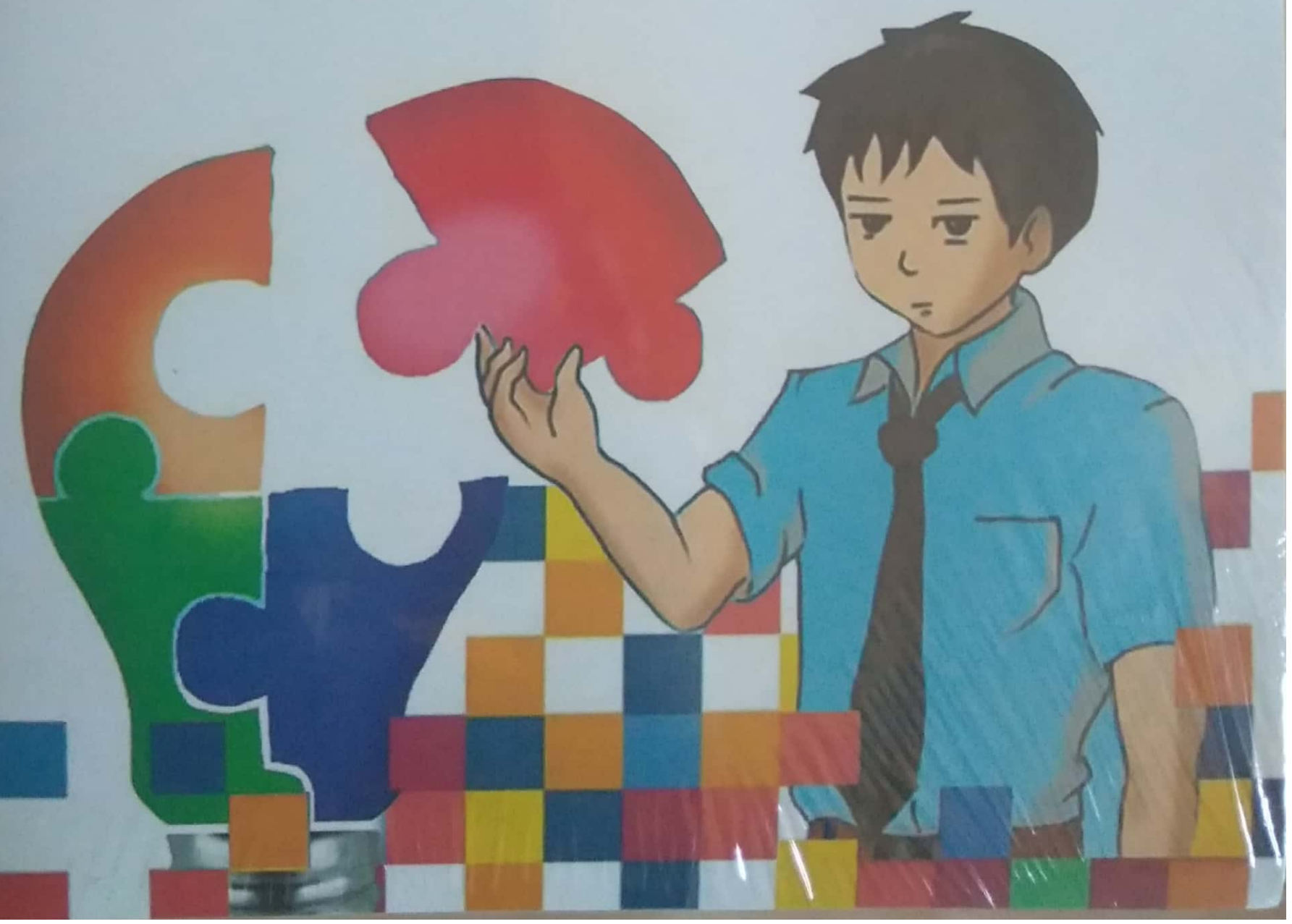


Pendidikan inklusi merupakan jawaban dari education for all dengan prinsip nilai-nilai universal yaitu kesetaraan (al musawa/equality), keadilan (al adalah/justice), kebebasan (al hurriyah/freedom), yang memberi peran difabel dalam pendidikan. Pendidikan inklusi menuntut sekolah melakukan penyesuaian dalam berbagai sarana dan prasarana yang menunjang, strategi serta metode pembelajaran yang mampu memenuhi kebutuhan siswa berkebutuhan khusus, terlebih pada sekolah inklusi reguler penuh.

Sebagaimana diketahui bahwa pendidikan agama Islam masih menggunakan metode ceramah dan bersifat hafalan. Hal tersebut menjadi kendala bagi siswa tunarungu di kelas inklusi, menjadi tuntutan bagi guru untuk melakukan pemilihan metode yang disesuaik yang selama ini masih bersifat individual. Disamping itu, tidak tersediaannya guru pendamping khusus di kelas inklusi yang menjadi permasalahan pada sekolah inklusi saat ini. Maka salah satu yang memungkinkan adalah dengan memodifikasi metode pembelajaran yang dapat diterima semua siswa pada kelas inklusi.

Salah satu metode yang saat berkembang adalah metode visual thinking, yaitu suatu metode yang memperhatikan karakteristik baik visual, audio dan kinetik. Penulis mengulas pembelajaran siswa tunarungu pada kelas inklusi dengan metode tersebut dalam buku yang berjudul "Visual Thinking Siswa tunarungu dalam Pembelajaran Pendidikan Agama Islam pada Kelas Inklusi". Berdasarkan hasil analisis temuan peneliti mengkontruksi metode pembelajaran dengan istilah Integrating Visual Thinking Method merupakan metode yang mengkolaborasi metode berpikir visual dan pendekatan strategi berpikir visual. Yaitu menginterasikan metode berpikir visual dengan konsep looking, seeing, imagining,thinking, telling and showing. Hal tersebut sebagai solusi pembelajaran yang menggerakkan siswa aktif baik sebagai subyek maupun obyek pembelajaran.
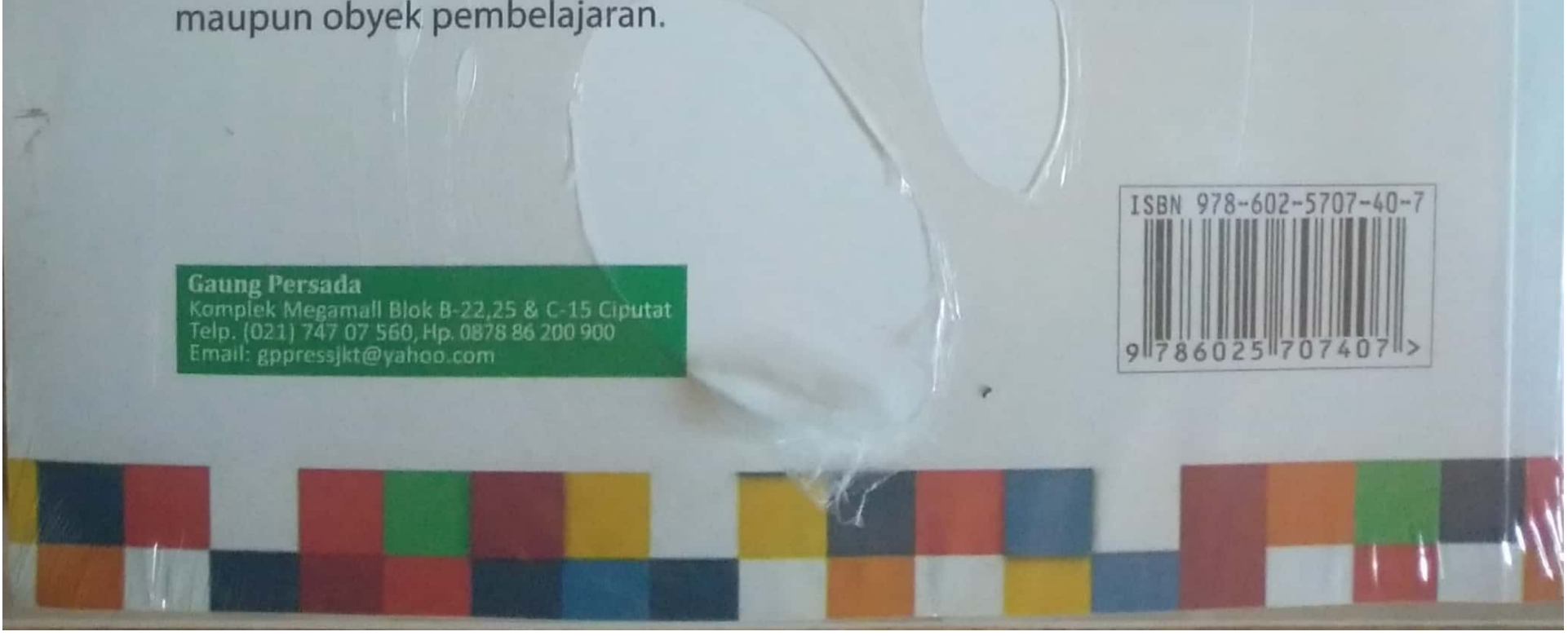
VISUAL THINKING SISWA TUNARUNGU DALAM

PEMBELAJARAN PENDIDIKAN AGAMA ISLAM

PADA KELAS INKLUSI

AMALIYAH

penerbit 


\section{KATA PENGANTAR}

Puji syukur kehadirat Allah subhanahu wa taala atas segala rahmat dan karunia-Nya sehingga peneliti dapat menyelesaikan disertasi dengan judul "Visual Thinking Siswa Tunarungu dalam Pembelajaran Pendidikan Agama Islam pada Kelas Inklusi". Shalawat teriring salam senantiasa kita sanjungkan kepada Muhammad sholawahu alaihi wassalam beserta keluarga, sahabat dan ummatnya.

Pendidikan inklusi merupakan jawaban dari education for all dengan prinsip nilai-nilai universal yaitu kesetaraan (al musawa/equality), keadilan (al adalah/justise), kebebasan (al hurriyah/freedom), yang memberi peran difabel dalam pendidikan. Pendidikan inklusi menuntut sekolah melakukan penyesuaian dalam berbagai sarana dan prasarana yang menunjang, strategi serta metode pembelajaran yang mampu memenuhi kebutuhan siswa berkebutuhan khusus, terlebih pada sekolah inklusi reguler penuh.

Sebagaimana diketahui bahwa pendidikan agama Islam masih menggunakan metode ceramah dan bersifat hafalan. Hal tersebut menjadi kendala bagi siswa tunarungu di kelas inklusi, menjadi tuntutan bagi guru untuk melakukan pemilihan metode yang disesuaikan dengan siswa berkebutuhan khusus, yang selama ini masih bersifat individual. Disamping itu, tidak tersediaannya guru pendamping khusus di kelas inklusi yang menjadi permasalahan pada sekolah inklusi saat ini. Maka salah satu yang memungkinkan adalah dengan memodifikasi metode pembelajaran yang dapat diterima semua siswa pada kelas inklusi.

Salah satu metode yang saat ini berkembang adalah metode visual thinking, yaitu suatu metode yang memperhatikan karakteristik baik visual, audio dan kinetik. Penulis mengulas pembelajaran siswa tunarungu pada kelas inklusi dengan metode tersebut dalam buku yang berjudul "Visual Thinking Siswa tunarungu dalam Pembelajaran Pendidikan Agama Islam pada Kelas Inklusi”. Berdasarkan hasil analisis temuan peneliti mengkonstruk metode pembelajaran dengan istilah Integrating Visual Thinking Method merupakan metode yang mengkolaborasi metode berpikir visual dan pendekatan strategi berpikir visual. Yaitu mengintegrasikan metode berpikir visual dengan konsep looking, seeing, imagining, thinking, telling and showing. Hal tersebut sebagai solusi pembelajaran yang menggerakkan siswa aktif baik sebagai subyek maupun obyek pembelajaran.

Peneliti mengucapkan terima kasih kepada semua pihak atas segala bantuan dan dukungannya kepada peneliti mulai dari awal masuk kuliah doktoral pascasarjana UIN Syarif Hidayatullah Jakarta sampai dengan terselesaikannya penyusunan disertasi ini. Ucapan terima kasih penulis secara khusus disampaikan kepada:

1. Direktur Sekolah Pascasarjana UIN Syarif Hidayatullah Jakarta, Prof. Dr. H. Jamhari, MA beserta keluarga besar civitas akademika sekolah Pascasarjana UIN Syarif Hidayatullah Jakarta. 
2. Ketua Program Doktor Sekolah Pascasarjana UIN Syarif Hidayatullah Jakarta. Prof. Dr. Didin Saepudin, M.A beserta seluruh dosen Sekolah Pascasarjana UIN Syarif Hidayatullah Jakarta.

3. Promotor I dan II. Prof. Dr. H. Dede Rosyada, M.A dan Prof. Dr. H. Husni Rahim atas bimbingan dan arahannya selama proses penyusunan disertasi ini sampai selesai.

4. Team penguji yang telah memberi masukan dalam penulisan, yaitu Prof. Dr. Sutjipto, Prof. Dr. Abuddin Nata, M.A., Prof. Dr. Armai Arief, M.Ag.

5. Kepala Sekolah SMAN 54 Jakarta Timur, H. Muqodas dan guru pendidikan agama Islam yaitu bapak Yusuf, bapak Ramdani, bapak Solihin, guru bagian kurikulum, guru bagian kesiswaan, guru yang bertugas untuk siswa berkebutuhan khusus, dan seluruh warga sekolah sehingga peneliti dapat menyelesaikan studi S3 dengan baik.

6. Dekan Fakultas Ekonomi, H. Endang Ruhayat, S.E.,M.M., CSRA, CMA., Ketua Prodi Akuntansi, Effriyanti, S.E.,Akt.,M.Si, CA, dan teman-teman dosen universitas Pamulang serta teman-teman di Sekolah Pasca sarjana UIN Syarif Hidayatullah Jakarta khususnya angkatan 2016/2017, terkhusus pada Dr. Fajar Syarif, Abdurrahman hakim, Dr. Siti Nasichatun, Dr. Masrofah, Dr. Ai Nurbayinah yang selalu menyemangati peneliti, semoga Allah SWT membalas kebaikan mereka.

7. Keluarga besar tercinta. Bapak Nasrudin (Alm) dan Ibu Faizah (Almh) yang selalu hidup di hati peneliti. Bapak mertua La Kudra (Alm) dan Ibu mertua Wa Salma (Almh), terkhusus suami tercinta La Ca Muhammad.SS, beserta putra putri kami terkasih Amirah Mulawizatul Luqya Lacaputri, M.Lukman hakim Lacaputra, M. Laqif Faiz Lacaputra, atas segala keikhlasan dan dukungannya yang tiada henti sehingga penulis dapat menyelesaikan studi doktoral ini.

Teriring doa yang tulus dari penulis, semoga Allah SWT berkenan membalas dengan pahala atas segala budi baik dan bantuan semua pihak. Penulisan buku ini tentu masih terdapat kekurangan, untuk itu segala kritik dan saran yang konstruktif dan mengarah pada penyempurnaan sangat penulis harapkan. Akhir kata, semoga buku ini dapat bermanfaat bagi para pembaca.

Jakarta, 17 Maret 2020

Penulis 


\section{DAFTAR ISI}

KATA PENGANTAR

DAFTAR ISI

DAFTAR TABEL

DAFTAR GAMBAR

\section{BAB I PENDAHULUAN}

A. Latar Belakang Masalah...................................1

B. Permasalahan

1. Identitas Masalah.......................................11

2. Perumusan Masalah.....................................12

3. Pembatasan Masalah.......................................12

C. Tujuan dan Signifikasi Penelitian...............................13

D. Manfaat Penelitian..............................................13

E. Penelitian Terdahulu yang Relevan............................13

F. Metode Penelitian

1. Jenis Penelitian......................................................................17

2. Pendekatan Penelitian............................................................. 17

3. Sumber Data........................................................................ 18

4. Tehnik Pengumpulan Data.....................................................21

5. Tehnik Analisa Data...............................................................24

G. Sistematika Penulisan......................................27

\section{BAB II KONSEP VISUAL THINKING DALAM PEMBELAJARAN PENDIDIKAN AGAMA ISLAM DI KELAS INKLUSI}

A. Metode Pembelajaran Siswa tunarungu...........................29

1. Karakteristik Siswa Tunarungu dalam Pembelajaran.............. 32

2. Metode Siswa Tunarungu dalam Pembelajaran.....................37

B. Kelas Inklusi dalam Pembelajaran Pendidikan Agama Islam... 39

1. Realitas Pendidikan Agama Islam pada Kelas Inklusi.............45

2. Kompetensi Pendidikan Agama Islam pada Kelas Inklusi...... 48

C. Visual Thinking dalam Pendidikan Agama Islam.........................60.

1. Konsepsi Visual Thinking..................................60

2. Visual thinking dalam Perspektif Islam .....................66

3. Visual Thinking pada Kelas Inklusi.................................74

\section{BAB III PROFIL PEMBELAJARAN PENDIDIKAN AGAMA ISLAM PADA SISWA TUNARUNGU DI SMAN 54 JAKARTA}

A. Gambaran Umum SMAN 54 Jakarta..........................................81

1. Profil SMAN 54 Jakarta.......................................................81

2. Visi Misi SMAN 54 Jakarta..................................................82

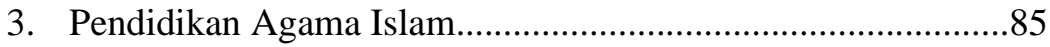

B. Realitas Kelas Inklusi pada Pembelajaran........................89

1. Perencanaan Pembelajaran....................................................90

2. Proses Pembelajaran...............................................................95 
3. Evaluasi Pembelajaran........................................................... 99

C. Problematika Pembelajaran Siswa Tunarungu....................103

1. Pengajaran Guru..................................................................

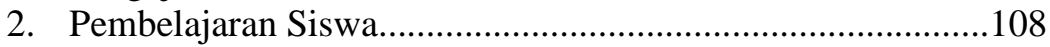

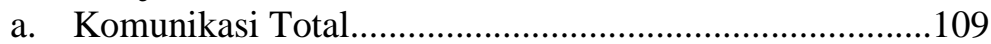

b. Aplikasi Live Trancribe …………………………...........112

BAB IV IMPLIMENTASI VISUAL THINKING DALAM PEMBELAJARAN PENDIDIKAN AGAMA ISLAM BAGI SISWA TUNARUNGU

A. Strategi Visual Thinking dalam Pembelajaran Pendidikan Agama Islam di Kelas Inklusi.

1. Penerapan visual thinking.........................................................118

2. Evaluasi visual thinking ...........................................................124

B. Visual thinking dalam Penilaian pengetahuan, sikap, ketrampilan siswa terhadap pembelajaran Pendidikan Agama Islam.

1. Penilaian Kompetensi Pengetahuan............................................150

2. Penilaian Kompetensi Ketrampilan.........................................155

3. Penilaian Kompetensi Sikap...................................................161

C. Penerapan visual thinking dalam pembelajaran Pendidikan Agama Islam bagi siswa tunarungu.

1. Faktor Pendukung 170

2. Faktor Penghambat....................................................................175

BAB V EVALUASI DAN RELEVANSI VISUAL THINKING DALAM PEMBELAJARAN PENDIDIKAN AGAMA SLAM BAGI SISWA TUNARUNGU

A. Signifikansi Implimentasi Visual Thinking Pada Kelas Inklusi

1. Pandangan Siswa Tunarungu.............................................. 184

2. Pandangan Siswa Sekelas..................................................... 185

3. Pandangan Orangtua............................................................ 186

4. Pandangan Guru................................................................ 187

B. Solusi bagi Siswa Tunarungu Pada Pembelajaran Pendidiikan Agama Islam.

1. Sosialisasi Visual Thinking.................................................. 188

2. Persiapan Guru................................................................... 188

3. Dampak penerapan Visual Thinking................................... 195

C. Evaluasi Hasil Temuan Visual Thinking Siswa Tunarungu.

1. Visual Thinking pada Prestasi Akademik Siswa.................. 199

2. Kemampuan Daya Ingat dalam Visual Thinking.................. 201

3. Kemampuan Daya Pikir dalam Visual Thinking.................. 203

4. Kemampuan Mencari Solusi dalam Visual Thinking........... 208

D. Integrating Visual Thinking method........................................... 211

1. Kolaborasi Metode Pembelajaran....................................... 213

2. Pendekatan Visual Thinking............................................... 219

3. Konsep Integrating Visual Thinking Method................ 221 


\section{BAB VII PENUTUP}

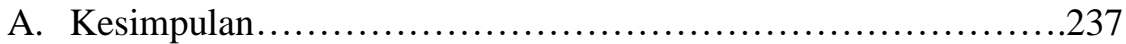

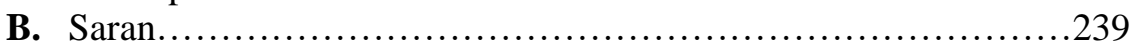

\section{GLOSARIUM}

DAFTAR PUSTAKA

INDEKS

LAMPIRAN 


\section{DAFTAR TABEL}

Tabel 1.1 Data Sekolah Wilayah Jakarta.................. 4

Tabel 1.2 Data Sekolah Inklusi di Wilayah Jakarta.......... 4

Tabel 1.3 Informan Struktural SMA 54 Jakarta............. 22

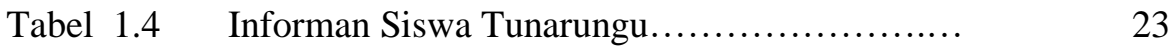

Tabel 1.5 Pengolahan Data ............................. 25

Tabel. 2.1 Klasifikasi Tunarungu $\quad$..................... 33

Tabel 2.2 Daftar Usia dan Pengenalan Konsep Bahasa..... 34

Tabel 2.3 Konsep Visual Comunication $\quad$................

Tabel 2.4 Konsep Visual Thinking Barat................... 64

Tabel 2.5 Proses Berpikir Visual ….................. 64

Tabel 2.6 Klasifikasi Visual Thinking dalam perspektif Islam 68

Tabel 2.7 Deskripsi Kesesuaian Konsep Visual Thinking Pendidikan Agama Islam..................................... 74

Tabel 3.1 Identitas SMAN 54........................... 80

Tabel. 3.2 Materi RPP kelas XI ........................... 89

Tabel 3.3 Kelas XI, Semester 2 Pertemuan 5 Masa Kejayaan Islam 90

Tabel. 3.4 Kompetensi Inti Perkembangan peradaban Islam pada masa kejayaan........................................... 90

Tabel. 3.5 Kompetensi Dasar dan Indikator Pencapaian Kompetensi................................... 91

Tabel. 3.6 Tujuan Pembelajaran Masa Kejayaan Islam........ 92

Tabel. 3,7 Langkah -langkah Visual Thinking pada Masa Kejayaan Islam...................................... 93

Tabel 3.8 Ilustrasi Visual Thinking pada materi kejataan Islam...................................... 95

Tabel 3.9 Penilaian Hasil Pembelajaran Skala Sikap.......... 97

Tabel. 3.10 Penilaian Membaca dengan Tartil Siswa Tunarungu.................................... 98

Tabel. 3.11 Penilaian Diskusi................................... 99

Tabel. 3.12 Remidial Siswa.................................. 100

Tabel 3.13 Bentuk Ekspresi................................ 106

Tabel 4.1 Pelaksanaan Pendidikan Agama Islam pada Guru 127

$\begin{array}{lll}\text { Tabel. 4.2 Perbedaan tiga guru terhadap siswa Tunarungu.... } & 128\end{array}$

Tabel 4.3 Pelaksanaan Pembelajaran Pendidikan Agama Islam. 129

Tabel 4.4 Pelaksanaan Pembelajaran Pendidikan Agama Islam pada Siswa Tunarungu......................... 132

Tabel. 4.5 Capaian Hasil Penilaian Siswa Tunarungu........ 134

Tabel 4.6 Tahapan Asesmen............................. 136.

Tabel. 4.7 Standar Isi Pembelajaran Visual Thinking.......... 139

Tabel 4.8 Fasa-Fasa Pengajaran Berasaskan Model Visual Thinking 140

Tabel. 4.9 Lulusan yang Sebenarnya....................... 141

Tabel. 4.10 Proyeksi Eksistensi Pendidikan.................. 144

Tabel 4.11 Rentang Nilai Kompetensi Pengetahuan........... 145

Tabel. 4.12 Nilai Pengetahuan XI IPS 1..................... 146 
Tabel. 4.13 Hasil Nilai Pengetahuan Luthfia................... 147

Tabel. 4.14 Hasil Nilai Pengetahuan M. Faridzan............... 147

Tabel..4.15 Nilai Pengetahuan XI IPS 3 ...................... 148

Tabel. 4.16 Hasil Nilai Pengetahuan Adiva.................... 149

Tabel..4.17 Nilai Pengetahuan M. Raihan....................... 149.

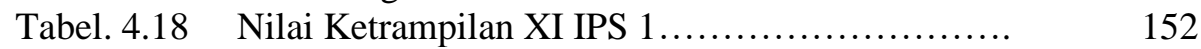

Tabel. 4.19 Nilai Ketrampilan Luthfia........................... 153

Tabel. 4.20 Nilai M.Faridzhan.................................... 153

Tabel $4.21 \quad$ Nilai Ketrampilan XI IPS 3....................... 154

Tabel. 4.22 Nilai Ketrampilan Adiva............................ 155

Tabel 4.23 Nilai Ketrampilan M.Raihan...................... 155

Tabel..4.24 Rentang Nilai Kompetensi Sikap................... 157

Tabel. 4.25 Nilai Sikap kelas XI IPS $-1 \ldots \ldots \ldots \ldots \ldots \ldots \ldots \ldots \ldots . . \ldots \ldots \ldots$

Tabel 4.26 Nilai Sikap XI IPS 3............................ 161

$\begin{array}{ll}\text { Tabel. 4.27 } & \text { Kebijakan Sekolah Ditinjau dari } \\ & \text { Faktor Pendukung Visual Thinking................... }\end{array}$

Tabel 4.28 Metode Ditinjau dari

Faktor Pendukung Visual Thinking.................. 166

Tabel 4.29 Kompetensi Guru Ditinjau dari

Faktor Pendukung Visual Thinking ...................... 167

Tabel 4.30 Kompetensi Siswa Ditinjau dari

Faktor Pendukung Visual Thinking....................... 169

Tabel 4.31 Kompetensi Guru Ditinjau dari

Kendala Visual Thinking................................. 171

Tabel 4.32 Kompetensi Siswa Ditinjau dari

Kendala Visual Thinking.................................. $\quad 172$

Tabel 4.33 Metode Ditinjau dari

Kendala Visual Thinking.................................. 173

Tabel 4.34 Kebijakan Sekolah Ditinjau dari

Kendala Visual Thinking................................ 176

Tabel. 5.1 Manfaat visual thinking

bagi siswa tunarungu............................ 184

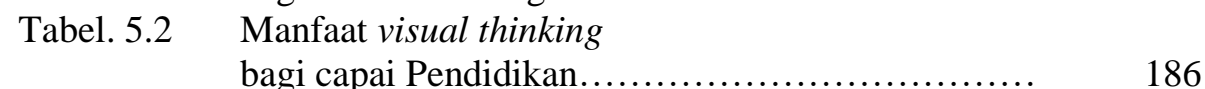

Tabel 5.3 Langkah Solusi bagi Tugas Guru................... 187

Tabel 5.3 Proses Berpikir

Tabel. 5.4 Unsur-Unsur Ketrampilan Berpikir..................... 223

Tabel 5.5 Manfaat Integreting Visual Thinking Method

$\begin{array}{ll}\text { Tabel 5.6 } & \begin{array}{l}\text { Eksistensi Pendidikan dalam } \\ \text { Integrating Visual Thinking Method................... }\end{array}\end{array}$ 


\section{DAFTAR GAMBAR}

Bagan 1.1. Data Statistik Difabel di Jakarta ................ 4

Bagan 1.2 Data Difabel berdasarkan kekhususan............. 4

Bagan 1.3 Jumlah Sekolah Luar Biasa di Jakarta............. 6

Bagan 2.1 Penilaian Pengetahuan.......................... 49

Bagan 2.2. Penilaian Sikap............................... 53

Bagan 2.3. Penilaian Ketrampilan......................... 55

Bagan.3.1 Model Pembelajaran Kurikulum 2013............ 87

Bagan 3.2 Komunikasi Total.............................. 107

Bagan 4.1 Peran Visual Thinking dalam Penyampaian Pesan 117

Bagan 4.2 Perencanaan dan Evaluasi Program Visual Thinking dalam Pendidikan agama Islam ................... 137

Bagan. 5.1 Hubungan Keterkaitan Tunarungu, Visual Thinking dan Sekolah Inklhusi.............................. 192

Bagan 5.2 Indikator Visual Thinking memudahkan Siswa dalam Pembelajaran............................... 195

Bagan 5.3 Prestasi Akademik Siswa dalam Visual Thinking..... 197

Bagan 5.4 Penerapan Proses Berpikir dalam Pembelajaran..... 202

Bagan 5.5 Integreting Visual Thinking Method................. 206

Bagan 5.6 Sumber Data Integreting Visual Thinking Method........207

Bagan 5.7 Konsep Visual Thinking Barat...................... 208

Bagan 5.8 Konsep Visual Thinking Perspektif Islam.............. 211

Bagan 5.9 Visual Thinking Pemikiran Ramlah.................. 213

Bagan 5.10 Hubungan Karakteristik dengan Metode.................. 217

Bagan 5.11 Siklus Karakteristik Siswa....................................... 218

Bagan.5.12 Siklus Visual Thinking yang belum maksimal

Bagan 5.13 Tempat duduk siswa.............................. 220

Bagan 5.14 Kemandirian Siswa pada Pendidikan Agama Islam... 224 


\section{BAB I PENDAHULUAN}

\section{A. Latar Belakang Masalah}

Interaksi sosial merupakan fitrah individu, sebagai proses komunikasi untuk menjalin hubungan antar individu, individu dengan kelompok dan kelompok dengan kelompok. ${ }^{1}$ Salah satu proses komunikasi dalam interaksi sosial adalah melalui pendidikan. Terutama dalam mengembangkan seluruh potensi kemanusiaannya, baik potensi individualitas, sosialitas, moralitas maupun religiusitasnya, ${ }^{2}$ sebagaimana misi utama kerasulan Muhammad yaitu memberikan rahmat dan kebaikan bagi seluruh ummat dan alam semesta. ${ }^{3}$

Menurut Azra, bahwa salah satu misi sentral nabi Muhammad SAW adalah misi profetis, yaitu mendidik manusia kepada perubahan yang bersifat sistematis, gradual dan berkesesinambungan, khususnya dalam upaya restorasihumanis terhadap moralitas manusia ke arah kesempurnaan hidup. ${ }^{4}$ Maka proses pendidikan tidak berlangsung di ruang kosong dan terisolasi, melainkan di tengah hiruk pikuk masyarakat yang berubah cepat. Ini artinya, apa yang terjadi dalam masyarakat cepat atau lambat akan berpengaruh secara signifikan terhadap bidang pendidikan.

Sebagaimana yang diterangkan al Quran surat al-Isra' ayat 21, yang mengisyaratkan adanya perbedaan individu antar manusia. Siswa adalah individu yang memiliki perbedaan karakteristik dari kesiapan dan kemampuan fisik, psikis, serta intelektual. Oleh karena itu, harus terjadi perubahan orientasi dari pedagogik dalam paradigma sempit ke arah pedagogik pemberdayaan, ${ }^{5}$ dimana pendidikan bukan hanya sekedar membuat siswa pandai menghafal, tetapi lebih penting menjadikannya sebagai manusia, sebagaimana makna belajar menurut al-Ghazali sebagai proses memanusiakan manusia. ${ }^{6}$

Keberhasilan pendidikan sangat tergantung pada individu manusia sebagai aktor pendidikan, adapun lingkungan sekitar yang berperan sebagai fasilitatornya. Pada proses alamiah, terdapat manusia yang memiliki hambatan dalam komunikasi, yaitu kekurangan pada fungsi bagian organ tubuh (difabel),

${ }^{1}$ Deddy Mulyana, Ilmu Komunikasi:Suatu Pengantar, (Bandung: Remaja Rosdakarya, 2005), h. 15.

2 Peters, Susan.J, "Inclusive Education: An EFA Strategy for All Children", artikel ini diakses pada 1 oktober 2019 dari www.worldbank.org, 2003.

3 Zamroni, Pendidikan untuk Demokrasi: Tantangan Menuju Civil Society, (Yogyakarta Bigraf, 2001), h. 24.

4 Azyumardi Azra, Pendidikan Islam: Tradisi dan Modernisasi di Tengah Tantangan Milenium III (Jakarta: Prenadamedia Group, 2014), h. 61-62.

${ }^{5}$ Mohd Zailani, etc., "Direction of Moral Education Teacher to Enrich Character Education”, JIP-International Multidisciplinary Journal, Vol. 3, No. 1, 2015, h. 119132.

${ }^{6}$ Solichin, "Belajar dan Mengajar dalam Pemandangan Al Ghozali", Jurnal Tadris, Vol. 1 No. 1, 2006, h. 139-153. 
seperti kurang dalam pendengaran, penglihatan dan pelafadzan, sehingga berpengaruh pada efektifitas proses pendidikan yang dilakukan. ${ }^{7}$

Keadilan pendidikan telah dijelaskan dalam pandangan universal "education far all", sebagaimana al-Quran menjelaskan kosa kata tuli (shummun), bisu (bukmun), buta (umyun) digunakan sebagai makna metafor (majaz) seperti penggunaan tiga kata tersebut dalam al Baqarah ayat 18 dimaksudkan untuk menyebut orang yang tidak menerima kebenaran.

Secara filosofis, inklusi sudah tersirat dalam semboyan Indonesia, "Bhineka tunggal ika". Artinya tidak terciptanya dikotomi pada masyarakat eksklusif normal dan tidak normal, karena kecacatan sebagai hal yang alami yang tumbuh di masyarakat. Secara agama, pendidikan inklusi sesuai dengan nilai-nilai universal Islam dalam menjawab bermacam perbedaan dalam kehidupan manusia yaitu kesetaraan (al-musawalequality), keadilan (al adalah/justise), kebebasan (al-hurriyah/freedom). Nilai-nilai tersebut mengapresiasi peran difabel dalam menjaga kehormatan.

Secara yuridis, UUD 1945 pasal 31 ayat 1 dan 2, UU No. 23 Tahun 2002 tentang perlindungan anak, UU No. 20 Tahun 2003 tentang sistem pendidikan nasional yang memberi ruang siswa berkebutuhan khusus untuk menunjukkan eksistensinya, yaitu pada pasal 5 ayat 1, bahwa hak yang sama untuk memperoleh pendidikan yang bermutu, baik yang memiliki kelainan fisik, emosional, mental, intelektual atau sosial.

Kemudian Permendiknas Nomor 22 tahun 2006 tentang standar isi untuk satuan pendidikan dasar dan menengah. Peraturan pemerintah Nomor 17 Tahun 2010 bahwa pendidikan khusus diselenggarakan melalui satuan pendidikan khusus, satuan pendidikan umum dan satuan pendidikan kejurusan. ${ }^{8}$ Sebetulnya tahun 1980 di Indonesia, program inklusi merupakan program kelanjutan pendidikan terpadu, tetapi kurang berkembang. Tahun 2004, Indonesia menyelenggarakan konvensi nasional dengan deklarasi Bandung, yaitu "Indonesia menuju pendidikan inklusi". Tahun 2005, simposium internasional di Bukit Tinggi untuk pendidikan inklusi yang berkualitas dan layak. ${ }^{9}$

Secara pedagogis, pada sistem segregasi, kecacatan siswa lebih ditonjolkan padahal dalam eksistensinya sebagai individu memiliki unik dan holistik yang tidak bisa diabaikan. Penyandang difabel berhak memperoleh kesempatan yang sama dengan siswa lainnya untuk mendapatkan pendidikan secara adil. Oleh karena itu, masalah mutu pendidikan tidak dapat dibentuk oleh faktor tunggal, artinya banyak faktor yang mempengaruhi dalam upaya meningkatkan mutu pendidikan. Hasil studi International for the Evaluation

${ }^{7}$ Ririn Fidiawati, "Peningkatan Kemampuan Artikulasi Melalui Metode Drill pada Anak Tuna Rungu Kelas Dasar II di SLB-YPPALB Kota Magelang”, (Universitas Negeri Yogyakarta, 2012), h. 1.

${ }^{8}$ Dedy Kustawan, Analisis Hasil Belajar: Program Perbaikan dan Pengayaan Peserta Didik Berkebutuhan Khusus, (Jakarta: Luxima, 2016), h. 8.

9 Kementrian Pendidikan Nasional, Modul Pelatihan Inklusi, (Jakarta: Kementrian Pendidikan Nasional, 2009), h. 10. 
Achievenment (IEA) di Asia Timur (2016), bahwa rata-rata siswa di Indonesia lebih dominan menghafal daripada pemahaman. ${ }^{10}$

Paparan Anies Baswedan bahwa 75\% sekolah di Indonesia tidak memenuhi standar layanan minimal pendidikan, karena nilai rata-rata kompetensi guru di Indonesia hanya 44,5, sedangkan nilai standar kompetensi guru adalah $75 .{ }^{11}$ Adapun hasil dari JPPI, terdapat 5 indikator, diantaranya governance, availability, accessibility, acceptability, dan adaptability, ${ }^{12}$ dimana ada 3 hal yang skor-nya masih rendah antara lain kualitas guru (availability), sekolah yang belum ramah anak (acceptability), pendidikan atau akses bagi kelompok-kelompok marginal (adaptability).

Saat ini, pendidikan inklusi merupakan program alternatif nasional dalam rangka pemenuhan hak pendidikan yang dijiwai oleh semangat non diskriminatif. Namun dalam pelaksanaan pendidikan, terdapat permasalahan yaitu siswa difabel susah mendapatkan sekolah inklusi yang memenuhi kebutuhannya. Bahkan sekolah yang sudah dikatakan inklusi-pun hanya memenuhi kewajiban dari pemerintah untuk penyediaan 5\% khusus siswa difabel, tanpa penyediaan sarana dan prasarana yang memadahi, dengan ketentuan hanya siswa difabel yang memiliki hambatan sedang atau ringan yang dapat dididik di sekolah inklusi. ${ }^{13}$

Siswa difabel masih mengalami berbagai hambatan dalam sekolah inklusi, faktor pertama, dedikasi dan kesiapan guru, karena kebanyakan guru belum memahami karakteristik dan gaya belajar siswa difabel. Faktor kedua, kurikulum dan aturan sekolah serta budaya lingkungan yang penerapannya kurang akomodatif, misalnya interaksi komunikasi dalam pembelajaran. ${ }^{14}$

Berdasarkan data PUSDATIN KEMENSOS (2010) terdapat 11.580.117 penyandang difabel di Indonesia yang perlu mendapatkan perhatian, baik tunanetra, tunarungu, tunagrahita, tunadaksa, tunalaras. ${ }^{15}$ Tahun 2016

${ }^{10}$ Cahya Cantika Amiranti, "Tak Ada Siswa yang Bodoh, Cek Lagi Cara Belajarnya", https://edukasi.kompas.com/read/2016/09/14/18310091/tak.ada.siswa. yang.bodoh.cek.lagi.cara.ajarnya.\#. Diakses 23 Nopember 2019.

${ }^{11}$ Anies Baswedan dalam pemaparan materi di hadapan kepala dinas pendidikan provinsi, kabupaten/kota se-Indonesia, di Kemendikbud, Senin (1/12/2014). Sebut Pendidikan Indonesia Gawat Darurat, http://edukasi.kompas.com/read/2014/12/ 01/13455441/.

12 Mohd Roslan Mohd Nor and Maksum Malim, the case of Indonesia, Department of Islamic History and Civilization, Academy of Islamic Studies, University of Malaya, Kuala Lumpur, Malaysia, Jurnal Revisiting Islamic education, TT, h.

${ }^{13}$ Filani Olivia, Satu Juta Anak Berkebutuhan Khusus Tak Bisa Sekolah, diakses pada 7 Pebruari 2019 dari https: //www. cnnindonesia. com/ nasional /20170829083026-20-237997/ satu- juta- anak- berkebutuhan- khusus- tak- bisasekolah.

${ }^{14}$ Irwanto dkk, Analisis situasi penyandang disabilitas di Indonesia, (Jakarta, UI, 2010), http://www.Ilo.Org/wcmsp5/Groups/Public/---Asia/---Ro-Bangkok/---IloJakarta/Documents/Publication/Wcms_160340.Pdf diakses 1 Desember 2019.

${ }^{15}$ Lihat: http:00m.liputan6.com, lihat juga Poskota News.com, diakses pada 25 Juli 2016. 
berdasarkan data difabel dari Badan Pusat Statistik (BPS) DKI Jakarta menjelaskan bahwa difabel yang dihitung usia 10 tahun ke atas mencapai 6.003 jiwa dengan katagori tertinggi di Jakarta Selatan 2.290 jiwa dan terendah di Kepulauan Seribu 69 jiwa.

Bagan. 1.1

\section{Data Statistik Difabel di Jakarta}

\section{Data Statistik Difabel di Jakarta}

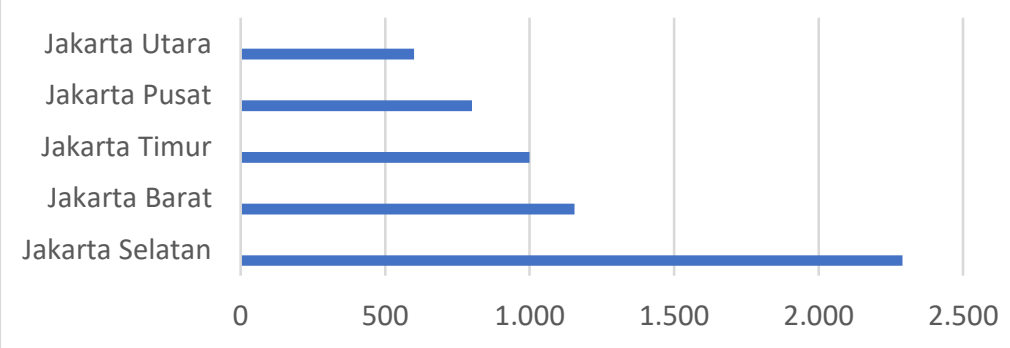

Sumber Data: Diolah peneliti berdasarkan BPS, 2016

Adapun data difabel secara spesifik berdasarkan kekhususannya berjumlah 5.271 difabel, $28 \%$ dari jumlah tersebut 1.509 jiwa merupakan penyandang tuna daksa, 11\% (587 jiwa) adalah tuna netra, 12.5\% (673 jiwa) adalah tunarungu, sisanya $22.8 \%$ merupakan penyandang difabel lainnya ${ }^{16}$, dengan bagan sebagai berikut:

Bagan. 1.2

Data Difabel Berdasarkan Kekhususan

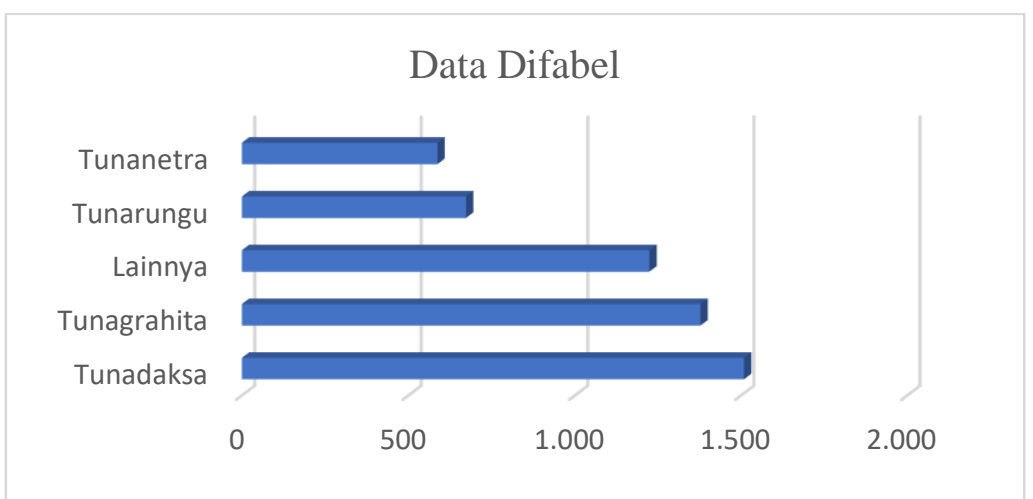

Sumber: Diolah peneliti berdasarkan data KPU, 2017.

${ }^{16}$ 5.271 Penyandang Disabilitas Terdaftar Pilkada DKI Jakarta 2017 di akses 24 Nopember 2019, pada file:///C:/Users/Acer/Downloads/5271-penyandangdisabilitas-terdaftar-pilkada-dki-jakarta-2017.pdf. 
Di DKI Jakarta telah diberlakukan surat keputusan gubernur No. 116 tahun 2007 tentang pelaksanaan pendidikan inklusi, dengan meminta secara jelas di setiap kecamatan harus diselenggarakan minimal 1 sekolah penyelenggaraan pendidikan inklusi di tingkat SD, SMP, SMA/SMK. ${ }^{17}$ Berdasarkan data sekolah reguler SMA/SMK berbanding sekolah inklusi di DKI Jakarta, ${ }^{18}$ sebagaimana tabel di bawah ini:

Tabel 1.1.

\section{Data Sekolah Wilayah Jakarta}

\begin{tabular}{|l|c|c|c|c|c|c|}
\hline \multirow{2}{*}{ Wilayah } & \multicolumn{3}{|c|}{ SMA/MA } & \multicolumn{3}{c|}{ SMK } \\
\cline { 2 - 7 } & Negeri & Swasta & Total & Negeri & Swasta & Total \\
\hline KepulauanSeribu & 1 & - & 1 & 1 & - & 1 \\
\hline Jakarta Barat & 30 & 104 & 134 & 12 & 107 & 119 \\
\hline Jakarta Pusat & 14 & 56 & 70 & 14 & 60 & 74 \\
\hline Jakarta Selatan & 35 & 94 & 129 & 17 & 118 & 135 \\
\hline Jakarta Timur & 66 & 102 & 168 & 13 & 172 & 185 \\
\hline Jakarta Utara & 23 & 74 & 97 & 8 & 68 & 76 \\
\hline \multicolumn{1}{|c|}{ Total } & $\mathbf{1 6 9}$ & $\mathbf{4 3 0}$ & $\mathbf{5 9 9}$ & $\mathbf{6 5}$ & $\mathbf{5 2 5}$ & $\mathbf{5 9 0}$ \\
\hline
\end{tabular}

Sumber Data: Dapodikdasmen, 2018.

Tabel 1.2

\section{Data Sekolah Inklusi di Wilayah Jakarta}

\begin{tabular}{|c|l|l|}
\hline No. & \multicolumn{1}{|c|}{ Wilayah } & \multicolumn{1}{c|}{ Sekolah Inklusi } \\
\hline 1 & Jakarta Pusat & SMUN 5, SMK 13, SMK 27, SMK 38 \\
\hline 2 & Jakarta Barat & SMUN 40, SMK 60, SMUN 112 \\
\hline 3 & Jakarta Utara & SMK 33, SMUN 40, SMK 49 \\
\hline 4 & Jakarta Selatan & SMK 30, SMK 32, SMUN 66 \\
\hline 5 & Jakarta Timur & SMK 24, SMUN 54, SMUN 58 \\
\hline
\end{tabular}

Sumber Data: Daposikdasman, 2018.

Dari tabel data sekolah reguler dan sekolah inklusi adalah $590: 17 .{ }^{19}$ Penanganan siswa berkebutuhan khusus juga dalam bentuk lembaga pendidikan formal yaitu sekolah luar biasa (SLB), sehingga siswa belajar sesuai dengan kekhususannya (tunanetra, tunarungu, tunagrahita, tunadaksa,

17 Irwanto, dkk, Analisis Situasi Penyandang Disabilitas di Indonesia, https://www.Ilo.Org/Wcmsp5/Groups/Public/---Asia/---Ro-Bangkok/---Ilo-

Jakarta/Documents/Publication/Wcms_160340.Pdf. Di akses 24 Nopember 2019.

${ }^{18}$ Dapodikdasmen, "Data Sekolah Wilayah Jakarta" diakses pada 7 Desember 2018 http //www .umm. ac.id /id/ pages/ dki- jakarta. html.

${ }^{19}$ Data Sekolah Inklusi di Wilayah Jakarta, diakses pada 7 Desember 2019, http:// rumaha dhd. blogspot. com/2012/01/ daftar- sekolah- inklusi- smun- smk.html. 
tunalaras, autis, low function). ${ }^{20}$ Adapun data jumlah sekolah luar biasa di Jakarta tahun 2016 sebanyak 90 unit, terbanyak di Jakarta Selatan 32 unit SLB dan di Jakarta Timur dengan 23 unit, dengan penjelasan tabel sebagai berikut:

Bagan 1. 3

\section{Jumlah Sekolah Luar Biasa di Jakarta}

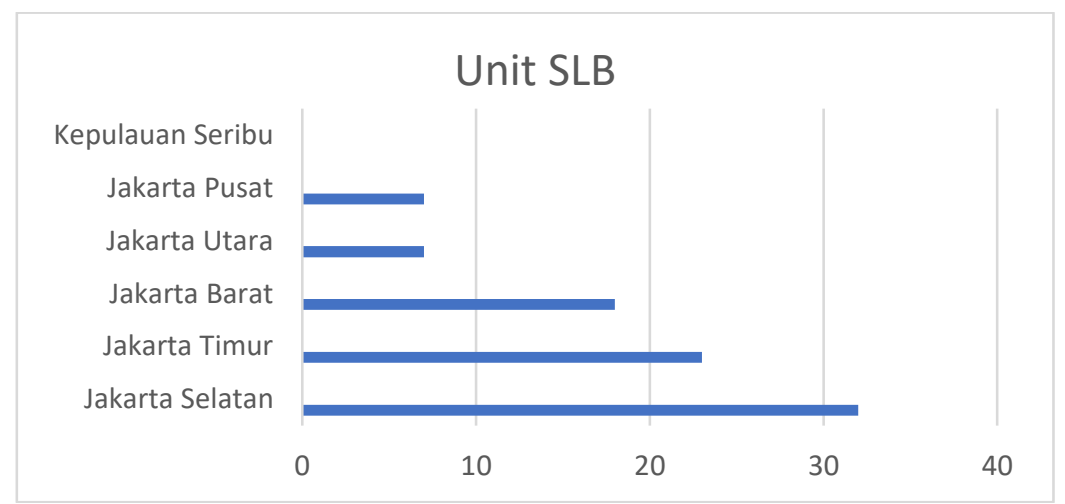

Sumber Data: Diolah peneliti berdasarkan Kementrian Pendidikan dan Kebudayaan, 2016.

Maka dari paparan data dapat diperbandingkan antara jumlah difabel dengan unit sekolah, baik inklusi maupun SLB masih membutuhkan perhatian. Perhatian tersebut terutama pada penjaminan mutu siswa difabel baik di SLB maupun di sekolah inklusi. Tantangan kompetensi yang sama antara siswa difabel dengan siswa pada umumnya. hal tersebut dimaksudkan agar kompetensi siswa difabel dapat digerakkan. Sekolah berperan untuk mewujudkan suasana kelas yang mendukung sistem normalisasi dan konsisten dengan gagasan keadilan sosial.

Realitanya masih terdapat stigma negatif pada masyarakat yang berpandangan bahwa difabel menjadi sebuah beban, bahkan masih banyak yang menutupi keberadaan difabel di lingkungan keluarga, padahal mereka memiliki potensi yang dapat berkembang dan bersaing serta bermanfaat bagi masyarakat. ${ }^{21}$

Sekolah sebagai tempat pengembangan individu diharapkan bisa menjawab tantangan peradaban universal, bagaimana sekolah mampu mengembangkan kreatifitas siswa normal maupun difabel, ${ }^{22}$ Pada pendidikan inklusi juga harus memperhatikan dua bidang kemandirian untuk siswa

${ }^{20}$ Dedy Kustawan, Analisis Hasil Belajar:Program perbaikan dan pengayaan peserta didik berkebutuhan khusus, (Jakarta: Luxima, 2016), h. 8.

21 Ni Nyoman Mika Putri Karuniasih, etc., Tinjauan Fenomenalogi atas Stigmatisasi Sosial Penyandang Disabilitas Tunarungu, file://C:/User/Acer/ download/26174-1-513411-10-20170110.Pdf. di akses 24 Nopember 2019.

${ }^{22}$ Cam Caldwell, Do X. Truong, Pham T. Link and Anh Tuan, "Strategic Human Resource Management As Ethical Stewardship", Journal of Business Ethics, Vol. 98, No. 1, 2011, h.171-182. 
berkebutuhan khusus yang harus dimiliki, yaitu pertama, ketrampilan dasar dalam hal membaca, menulis, berhitung, komunikasi. Kedua, ketrampilan perilaku adaptif yaitu ketrampilan mengurus diri (personal living skills), dan ketrampilan menyesuaikan diri (social living skills). ${ }^{23}$

Sejarah telah membuktikan sebagian tunarungu mampu berprestasi dan membuktikan eksistensinya di masyarakat. Di antaranya Helen Keller, ${ }^{24}$ Thomas Alva Edison (AS), ${ }^{25}$ Beethoven, ${ }^{26}$ Nashiru Abdulai. ${ }^{27}$ Terdapat juga siswa tunarungu yang telah membuktikan prestasinya dalam pembelajaran di Indonesia, antara lain Hendry Restiya Susetya, ${ }^{28}$ T. Mega anggoyo, ${ }^{29}$ Angkie Yudistia,${ }^{30}$ Dian Inggrawati Soebangil, ${ }^{31}$ Rafi Abdurrahman Ridwan. ${ }^{32}$ Akan tetapi, tunarungu dipatahkan dengan asumsi yang irasional pada kondisi fisik, sehingga ruang gerak mereka sempit, pengakuan yang sulit, kesempatan kerja dan penerimaan masyarakat, termasuk membuktikan bahwa prestasi mereka adalah asli bukan jiplakan dan patut dihormati. ${ }^{33}$

Pendidikan inklusi menuntut sekolah melakukan penyesuaian, baik kurikulum, sarana prasarana, sistem pembelajaran yang sesuai dengan siswa berkebutuhan khusus, karenanya proses pengkondisian dilakukan guru dengan

${ }^{23}$ Jati Rinakri Atmaja, Pendidikan dan Bimbingan Anak Berkebutuhan Khusus, (Bandung, Remaja Rosdakarya, 2018), h. 5.

${ }^{24}$ Peneliti wanita Amerika, aktivis politik, dosen. Dia tunanetra dan tunarungu pertama yang mendapatkan gelar sarjana seni. (Veronika yasinta, "Biografi Tokoh Dunia: Helen Keller, Tunarungu Pendobrak Keterbatasan", diakses pada 7 Pebruari 2019 dari https://internasional.kompas.com/read/2018/10/03/17521121/biografitokoh-dunia-helen-keller-tunarungu-pendobrak-keterbatasan?page=all).

${ }^{25}$ Dia tunarungu sejak remaja. Penemu bola lampu listrik, memperbaiki system pada telegraf, menemukan gramufon, alat putar lagu.

${ }^{26}$ Mendapatkan ke-tunarungu-an setelah dewasa, Harmoni music klasik Ludwig van Beethoven, komponis yang menciptakan Fur Elise. Sebagian besar lagu-lagu melegenda diciptakan setelah tunarungu.

27 Tokoh muslim Amerika, penderita tunarungu yang berkampanye tentang sholat, mendengarkan khotbah dan membaca Al Quran. Mendirikan Muslim Deaf Global (GDM) 2005 untuk memenuhi hak dan kebutuhan muslim tunarungu di seluruh dunia. Telah berkembang California, Virginia, Minnesota, Minois, Texas, Kanada, Ghana. Kemudian dalam konfrensi Internasional tunarungu November 2013 "Kamus bahasa Isyarat Islami setebal 376 halaman. ( KisahIslami.com 10 Agustus 2014).

${ }^{28}$ Merupakan siswa tunarungu juara 1 UN di Sekolah Umum. (SMK Pangudi Luhur Muntilan -Magelang). News 30 Mei 2012.

${ }^{29}$ Merupakan juara desain, juara berbagai perlombaan teknologi (SLB Kemala Bhayangkara 2 gresik), Jawa pos 11 April 2017.

${ }^{30}$ Penulis buku "Perempuan Tunarungu yang Menembus Batas. Mendirikan this able enterprise (2011) sebagai Chief excutive officer (CEO) di perusahaan yang bergerak di bidang social (Publishing/ penerbitan, pendidikan dan komunikasi.

${ }^{31}$ Sebagai miss deaf word 2011 dan miss deaf Europe 2011 di Praha (the $2^{\text {nd }}$ Runner up).

${ }^{32}$ Sebagai desainer yang rancangan bajunya dipakai secara khusus pada acara finalis America's Next Top Model di Bali. (14 tahun).

${ }^{33}$ Rahmah, "Mad'u: Disabilitas dalam Islam”, Jurnal Ilmu Dakwah Alhadharah, Vol. 15, No. 30, 2016, h. 53-61. 
strategi dan metode yang tepat untuk kelas inklusi. ${ }^{34}$ Siswa tunarungu juga memiliki kesempatan yang sama untuk berprestasi, karena kompetensi merupakan wujud sikap, berfikir, dan tindakan konsisten, baik dari segi ilmu pengetahuan, maupun dari sisi ketrampilan. Ukurannya dilihat setelah siswa mengikuti proses pada satuan pendidikan tertentu. ${ }^{35}$ Sebagai modal yang utama untuk bersaing dalam skala global, yang lebih menekankan pada sisi kemampuan dari sumber daya manusianya tersebut.

Terdapat dua hal yang menjadi hambatan bagi siswa difabel yaitu pertama, kesiapan dan dedikasi guru untuk memahami model pembelajaran siswa difabel. Kedua yaitu penerapan kurikulum, aturan sekolah dan budaya lingkungan kurang akomodatif, sehingga pada siswa tunarungu tidak terjadi komunikasi aktif. ${ }^{36}$ Untuk itu dalam proses belajar sangat dibutuhkan persiapan diri siswa. Kesiapan belajar siswa terkait pada tiga unsur proses pendidikan dasar antara lain input, proses dan output, misalnya siswa telah mengetahui atau membaca materi mata pelajarannya terlebih dahulu. Proses pendidikan yang disertai kesiapan belajar akan memudahkan siswa memberi respon positif dan mendukung pencapaian output dan tujuan pendidikan. Menurut Agoes Soejanto kesiapan diri siswa sangat penting untuk meraih keberhasilan dalam kegiatan belajar. ${ }^{37}$

Memperhatikan mutu pendidikan dan melihat tantangan ke depan terhadap tuntutan masyarakat. Maka pendidikan yang diterapkan memerlukan 4 (empat) hal. ${ }^{\mathbf{3 8}}$ Pertama, kemampuan berpikir kritis (critical thinking skill). Kedua, kreativitas (creativity). Ketiga, komunikasi (communication). Keempat, kolaborasi (collaboration). ${ }^{39}$ Sejalan dengan pemikiran Anies Baswedan bahwa proyeksi pendidikan abad 21 ada 3 komponen yang mendasar: Pertama, Karakter/akhlaq/moral (iman, taqwa, jujur, rendah hati) dan (Karakter kinerja (ulet, kerja/keras, tangguh, tidak mudah menyerah, tuntas). Kedua, Kompetensi (berpikir kritis, kreatif, komunikatif, kolaboratif/kerjasama). Ketiga, Literasi / keterbukaan wawasan (baca: budaya, teknologi, keuangan), sebagai tuntutan kompetensi siswa.

Pendidikan agama Islam selama ini masih menggunakan metode ceramah dan bersifat hafalan. Menurut pendapat Kurt Singer, pendidikan bukan hanya sekedar membuat siswa pandai menghapal tetapi yang lebih penting ialah

${ }^{34}$ Sunardi, Kecendrungan dalam Pendidikan Luar Biasa, (Jakarta: DITJEN DIKTI. 2012), h. 12.

${ }^{35}$ Mulyasa, Kurikulum Berbasis Kompetensi, (Bandung: Remaja Rosda Karya, 2014), h. 14.

${ }^{36}$ Irwanto, Analisis Situasi Penyandang Disabilitas di Indonesia: Sebuah DeskReview, (Jakarta: Pusat Kajian Disabilitas, 2010). Lihat juga https :// Www .Ilo. Org/ Wcmsp5/ Groups/'Public/---Asia/---Ro- Bangkok/---Ilo- Jakarta/ Documents/ Publication/ Wcms_160340.Pdf"' Cipta, 1991).

${ }^{37}$ Agoes Soejanto, Bimbingan Kearah Belajar yang Sukses, (Jakarta: Rineka

38 Veronica L. Diptoadi, "Reformasi Pendidikan di Indonesia Menghadapi Tantangan Abad 21", Jurnal Ilmu Pendidikan, Jilid 6, No. 3. Tt. h. 5

39 Veronica, "Reformasi Pendidikan ...., h. 7 
menjadikannya sebagai manusia. ${ }^{40}$ Untuk mencapai hal tersebut, membutuhkan metode yang dapat mengkomunikasikan materi dengan baik. Karena itu, Zetty Azizatun Ni'mah menuntut kepada guru untuk melakukan pemilihan metode yang disesuaikan dengan siswa. ${ }^{41}$

Urgensi metode dibanding dengan materi, dikenal dalam bahasa arab yaitu “Al-Thariqat Ahamm Min Al-Maddah”, bahwa metode jauh lebih penting dari pada materi. Sebagaimana dijelaskan dalam al-Quran terkait pentingnya pemilihan metode pada pelaksanaan sebuah proses pembelajaran yang sesuai dengan materi yang disampaikan, misalnya dalam QS. An Nahl (125) yang menjelaskan metode hikmah, metode nasehat, metode diskusi. ${ }^{42}$ Menurut Rahman, bahwa metode ceramah sebagai metode yang fleksibel, mudah dan murah. Sebab pendidik bisa melakukan adaptasi, membatasi waktu pelajaran dan juga pada meningkatkan prestasi siswa. ${ }^{43}$ Sedang Retno Marsitin berpendapat bahwa metode diskusi mempunyai prestasi lebih baik dibanding dengan menggunakan metode konvensional. ${ }^{44}$

Menurut Nurotun Mumtahanah, perlu adanya analisis komprehensif tentang metode pembelajaran yang dapat meningkatkan prestasi siswa, ${ }^{45}$ serta dapat mempengaruhi perubahan dalam diri manusia. ${ }^{46}$ Realitas yang ada menunjukkan bahwa siswa lebih menyenangi metode penyampaian yang komunikatif, meskipun materinya tidak begitu menarik. Bila penyampaiannya kurang tepat maka akan mengurangi esensi dari materi itu sendiri, dan pada akhirnya sulit dipahami oleh siswa.

Maka penggunaan metode membutuhkan media pembelajaran. Sebagaimana menurut Winkel, diperlukan kemampuan guru menggunakan media yang dijadikan metode (technical know-how), agar siswa memiliki ketertarikan terhadap materi tersebut, serta mewakili pesan yang disampaikan

40 Joni Rahmat Pramudia, "Orientasi Baru Pendidikan: Perlunya Reorientasi Posisi Pendidik dan Peserta Didik", Jurnal Pendidikan Luar Sekolah, Vol. 3 No.1, 2006, h. 29-38. Pedagogik kritis merupakan rekayasa pemikiran yang berupaya menyempurnakan pedagogik yang selama ini kita kenal sebagai pedagogik dalam paradigma sempit, yaitu pedagogik yang cenderung melihat persoalan pendidikan semata-mata sebagai masalah-masalah teknik di dalam kelas.

${ }^{41}$ Zetty Azizatun Ni’mah, "Implementasi Strategi Pembelajaran Pendidikan Agama Islam (Sebagai Solusi Problematika Pembelajaran PAI)",At-Tajdid, JurnalImuTarbiyah, Vol. 5, No. 1, 2016, h. 29-53.

${ }^{42}$ Suci Sarofah, "Hadist tentang Metode Pendidikan",di akses 15 Mei 2016 Http://Dillanazaly.Blogspot.Co.Id/2013/10/Hadist-Tentang-Metode-Pendidikan.Html.

${ }^{43}$ Fazlur Rahman, "Impact of Discussion Method on Students Performance", International Journal of Business and Social Science, Vol. 2, No. 7, 2011, h. 88.

${ }^{44}$ RetnoMarsitin, "Pendekatan Konstruktivisme pada Metode Diskusi dalam Meningkatkan Prestasi Belajar Matematika Siswa SMP Muhammadiyah 3 Kepanjen Malang”, Jurnal Inspirasi Pendidikan, Vol. 1, No. 1, 2016, h. 205-215.

${ }^{45}$ Nurotun Mumtahanah, "Penggunaan Media Visual dalam Pembelajaran PAI", Jurnal Al-Hikmah, Studi Keislaman, Vol. 4, No. 1, 2014, h. 91-141.

46 Joseph Chinyong Liow, "Muslim Identity, Local Networks, and Transnational Islam in Thailand's Southern Border Provinces", Model Asian Studies, Vol. 45, No. 6, 2011, h. 1383-1421. 
guru. ${ }^{47}$ Maka menurut Saiful, perlu pemilihan metode yang tepat dengan mempertimbangkan tingkat kematangan siswa, keadaan situasi, kualitas dan kuantitas fasilitas pendukung dan kemampuan guru. ${ }^{48}$

Idealnya untuk mendidik tunarungu, hal yang dipersiapkan adalah guru dalam mengajar perlu mengenali bagaimana cara belajar siswa tunarungu dan minat masing-masingnya. Penerapannya dalam tiga hal yaitu proses, konten dan produk. Untuk proses misalnya dengan memutar video atau penggunaan powerpoint materi. Untuk konten sesuai kurikulum inklusi. Untuk produk, guru melakukan ekspos dulu dengan media ekspresi sebagai jembatan siswa dalam menghasilkan produk sesuai dengan kemampuan masing-masing (menuangkan hasil pemahamannya). ${ }^{49}$

Penggunaan metode pembelajaran bagi siswa tunarungu, seringkali digunakan adalah metode pembelajaran individual dan pendampingan khusus seperti yang dilakukan di SDN Inklusif Klampis Ngasem 1/246 Surabaya melalui kolaborasi guru kelas dan guru pembimbing khusus untuk memberikan pengulangan materi bagi siswa difabel. ${ }^{50}$ Pengulangan materi bagi siswa berkebutuhan khusus memang sangat diperlukan untuk memberikan pemahaman secara komprehensip terhadap materi yang disampaikan, akan tetapi akan terkendala ketika jumlah anak berkebutuhan khusus dalam suatu sekolah tergolong banyak, sedangkan jumlah guru terbatas atau bahkan tidak tersedianya guru pembimbing khusus.

Siswa tunarungu dalam pembelajaran lebih menekankan pada faktor penglihatan, oleh karena itu metode yang digunakan harus sesuai dengan kebutuhan siswa tunarungu. Berpikir visual dapat dijadikan alternatif agar siswa paham dan mampu mengatasi permasalahan pelajaran, sebagaimana kelas VIII SMPN 1 Larangan, Pamekasan. ${ }^{51}$ Metode pembelajaran terus berkembang misalnya metode eksperimen, metode visual thinking. ${ }^{52}$ Metode visual thinking memiliki kesesuaian dengan kebutuhan siswa tunarungu, karena metode tersebut menekankan visualisasi dalam tahapan proses metode visual

47 Nunu Mahnun, "Media Pembelajaran (Kajian terhadap Langkah-langkah Pemilihan Media dan Implementasinya dalam Pembelajaran)", Jurnal Pemikiran Islam, Vol. 37, No. 1, 2012, h. 27-35.

48 Saiful Bahri Djamarah, Guru dan Anak Didik dalam Interaksi Edukatif, (Jakarta: Rineka Cipta, 2010), h. 162.

${ }^{49}$ Najela Shihab \& komunitas guru belajar, Diferensiasi : Memahami Pelajar untuk Belajar Bermakna dan Menyenangkan, (Tangerang : Literati, 2016), h. 166.

50 Restu Sani Izzati, "Implementasi Kurikulum 2013 bagi Peserta Didik Berkebutuhan Khusus di Sekolah Dasar Inklusif”, Jurnal Pendidikan Khusus, Vol. 7, No. 4, 2015, diakses melalui: https://jurnalmahasiswa.unesa.ac.id/index.php/jurnalpendidikan-khusus/article/view/13453.

51 Septi Dariyatul Aini dan Sri Indriati Hasanah, "Berpikir Visual dan Memecahkan Masalah: Apakah Berbeda Berdasarkan Gender?", JNPM (Jurnal Nasional Pendidikan Matematika), Vol. 3, No. 2, 2019 DOI: http://dx.doi.org/10.33603/jnpm.v3i2.2192, diakses pada 18 Pebruari 2020.

${ }^{52}$ Kamsinah, "Metode dalam Proses Pembelajaran: Study tentang Ragam dan Implementasinya",Jurnal Lentera Pendidikan, Vol. 11, No. 1, 2008, h.101-114. 
thinking. Kreatifitas guru dalam mengelola pembelajaran, menjadi salah satu alternatif yang paling memungkinkan agar permasalahan seperti kurangnya tenaga guru atau tidak tersedianya guru pembimbing khusus dalam lembaga pendidikan inklusi dapat teratasi. Visual thinking dimunculkan pertama kali oleh Bolton (2011) dengan konsep look, see, imagine, show. ${ }^{53}$ dan Ramlah (2017) yang merujuk pada Bolton dengan konsep looking, seeing, imagining, showing and telling. ${ }^{54}$

Rutinitas visual thinking digunakan sebagai metode campuran yang diterapkan untuk guru dan siswa di Universitas Amerika di Dubai. ${ }^{55}$ Visual thinking juga diterapkan di MTs Al-Hikmah, Bogor, bahwa hasil tes kemampuan konesksi matimatika siswa yang diajar dengan pendekatan visual thinking lebih baik dibanding hasil tes kemampuan dari pendekatan konvensional. ${ }^{56}$ SMAN 54 Jakarta telah menggunakan metode visual thinking, sebagaimana penerjemahan metode pembelajaran dalam RPP. Dimana pada SMAN 54 terdapat siswa tunarungu pada sistem kelas inklusi regular penuh.

Berdasarkan latar belakang tersebut, dibutuhkan metode pembelajaran yang memenuhi kebutuhan siswa tunarungu, juga siswa normal lainnya dalam konteks kelas inklusi reguler penuh. Di samping itu, menyelaraskan sistem belajar yang bersifat individual menjadi sistem belajar yang sesuai kebutuhan siswa dan menjawab permasalahan tidak tersedianya guru pembimbing khusus pada kelas inklusi regular penuh. Untuk itu, perlu dikaji tentang "Visual thinking Siswa Tunarungu dalam Pembelajaran Pendidikan Agama Islam pada Kelas Inklusi”.

\section{B. Permasalahan}

Berdasarkan pemaparan latar belakang tersebut di atas, peneliti memandang perlu dilakukan penelitian dari aspek pembelajaran. Hal ini penting untuk dilakukan sebagai wujud dukungan pada siswa berkebutuhan khusus (siswa tunarungu) dan dukungan pada kebijakan pemerintah dalam kelas inklusi.

\section{IdentifikasiMasalah}

Terdapat persoalan utama yang mendasar berhubungan dengan riset, dengan beberapa catatan permasalahan signifikan sebagai berikut:

a. Pendidikan di Indonesia masih tertinggal, yang dinilai dari faktor gavernance, availability, accessibility, acceptability dan adaptability.

${ }^{53}$ Bolton, S. Decoding Visual Thinking. Paper presented at Naver Workshop Visualizing Creative Strategies, Rio de Janeiro: Esdi. 2011, diakses 18 Pebruari 2020.

54 Ramlah, Rina Marlina, "Implementasi Teknik Visual Thinking Berbasis Pengoptimalan Fungsi Otak Kanan dalam Pencapaian Komunikasi Matimatis Siswa SMP”, Jurnal Sigma, Vol. 2 No. 2, 2017, h. 50-58.

55 Alain Gholam, "Visual Thinking Routines: a Mixed Methods Approach Applied to Student Teachers at the American University in Dubai", Journal of Inquiry \& Action in Education, Vol. 9 No. 1, 2017, h. 12.

56 Dyna Khoerunnisa, Pengaruh Pendekatan Visual Thinking terhadap Kemampuan Koneksi Matematis Siswa, (UIN, 2017). 
b. Stigma negatif terhadap difabel, yang masih berpandangan sebagai beban dan tidak berguna di lingkungan keluarga dan masyarakat.

c. Tunarungu dalam pendidikan nasional belum mendapatkan apresiasi yang memadahi.

d. Kompetensi siswa tunarungu belum dianggap mampu berkompetisi dengan siswa pada umumnya.

e. Metode pembelajaran pendidikan agama Islam di kelas inklusi regular penuh masih bersifat ceramah dan hafalan.

f. Metode visual thinking merupakan metode pembelajaran baru yang digunakan di sekolah inklusi.

g. Materi pembelajaran siswa tunarungu di kelas inklusi regular penuh dalam prakteknya belum maksimal dilakukan.

h. Standar kualitas sekolah untuk siswa tunarungu dalam pendidikan masih perlu ditingkatkan.

i. Pembelajaran siswa tunarungu selama ini masih bersifat individual.

j. Pembelajaran siswa tunarungu membutuhkan guru pendamping khusus.

\section{Perumusan Masalah}

Dengan memperhatikan identifikasi masalah tersebut, maka rumusan permasalahan pada penelitian ini tentang bagaimana visual thinking menjadi metode pembelajaran pendidikan agama Islam bagi siswa tunarungu di kelas inklusi? Pertanyaan permasalahan ini dapat diturunkan menjadi dua sub pertanyaan, yaitu:

a. Bagaimana konsep metode visual thinking dalam pembelajaran kelas inklusi?

b. Bagaimana implementasi metode visual thinking dalam pembelajaran pendidikan agama Islam bagi siswa tunarungu di kelas inklusi?

\section{Pembatasan Masalah}

Dengan rumusan permasalahan diatas, peneliti memberi batasan yakni:

a. Fokus penelitian

1) Penelitian ini secara spesifik membahas konsep dan implementasi metode visual thinking dalam pembelajaran pendidikan agama Islam bagi siswa tunarungu pada kelas inklusi.

2) Siswa tunarungu yang dimaksudkan dalam penelitian ini adalah siswa tunarungu yang telah memiliki kemampuan bahasa ujar atau KOMTAL (Komunikasi Total).

b. Lokasi penelitian

Bertempat di sekolah inkluisi yaitu SMAN 54 yang beralamat di J1. Jatinegara Timur IV, Rawa Bunga, Jatinegara, Jakarta Timur. Peneliti memilih SMAN 54 karena memiliki kriteria antara lain:

1) SMAN 54 sudah dinyatakan sebagai sekolah inklusi sejak tahun 2003/2004, sehingga secara pengalaman memiliki kemampuan dalam melihat kompetensi siswa berkebutuhan khusus. 
2) SMAN 54 merupakan sekolah rujukan dan sekolah rintisan kategori mandiri, Dari jumlah siswa 864 di SMAN 54 bahwa 5\% dari jumlah tersebut adalah siswa berkebutuhan khusus. 19 siswa yang memiliki hambatan belajar dan 23 siswa adalah siswa berkebutuhan khusus.

c. Waktu penelitian

Penelitian ini di mulai dari Juli 2017 hingga tahun 2019,

\section{Tujuan Penelitian}

Tujuan penelitian dari disertasi ini adalah:

1. Untuk menganalisis konsep metode visual thinking pada pembelajaran kelas inklusi.

2. Untuk menganalisis implementasi metode visual thinking dalam pembelajaran pendidikan agama Islam bagi siswa tunarungu di kelas inklusi

\section{Signifikasi Penelitian}

Penelitian ini secara signifikasi dibagi menjadi dua yaitu manfaat akademis dan praktis.

1. Manfaat Akademis:

a. Visual thinking menjadi solusi bagi siswa difabel dalam pendidikan agama Islam.

b. Munculnya teori terbarukan dari pembelajaran tunarungu dalam meningkatkan pendidikan Islam.

\section{Manfaat Praktis}

a. Penelitian ini dapat menjadi acuan pengambilan kebijakan bagi pemerintah pusat dan daerah terkait dengan pengembangan pendidikan untuk siswa tunarungu.

b. Bisa menjadi acuan bagi orangtua dalam memperlakukan anak tunarungu.

\section{E. Penelitian Terdahulu yang Relevan}

Literasi digunakan sebagai gambaran keterhubungan antara riset ini dengan penelitian terkait yang telah diteliti sebelumnya, guna menegaskan pengulangan pada kajian ruang penelitan yang sama. Diantaranya yang terkait antara lain:

Nurotun Mumtahanah ${ }^{57}$ dalam "Penggunaan Media Visual dalam Pembelajaran PAI", menjelaskan bahwa media mampu memperbaiki perilaku peserta didik, serta memotivasi dan meningkatkan prestasi siswa dengan cara bertahap, yaitu diperlukan analisis komprehensif dengan memperhatikan berbagai aspek.

57 Nurotun Mumtahanah, "Penggunaan Media Visual Dalam Pembelajaran PAI”, Al Hikmah, Jurnal Studi Keislaman, Vol. 4, No. 1, 2014, h. 91-141. 
Penelitian lain adalah Edy Surya $^{58}$ dalam "visual thinking dalam memaksimalkan pembelajaran matematika siswa dapat membangun karakter bangsa" menjelaskan bahwa model pembelajaran harus merefleksikan bakat minat siswa untuk berpikir kreatif. Sebagaimana dijelaskan oleh Ellys Ervyani ${ }^{59}$ bahwa pemilihan metode harus memperhatikan kecendrungan gaya belajar siswa.

Pada penelitian Nurotun Mumtahanah, hanya membahas pada sekolah dengan komposisi siswa yang normal. Adapun pada penelitian Edy Surya, penekanan pada pembelajaran matematika dan tidak dilakukan pada kelas inklusi. ${ }^{60}$ letak perbedaan dengan penelitian ini dengan penelitian Nurotun Mumtahanah adalah komposisi siswa yang dilakukan adalah pada sekolah inklusi yang dikhususkan siswa tunarungu, serta pengukuran tingkat kompetensi yang dihasilkan. Adapun perbedaan dengan penelitian Edy Surya, penelitian ini memaksimalkan pembelajaran PAI, kompetensi dan pada kelas inklusi.

Ridwan Effendi ${ }^{61}$ dalam "metode pembelajaran bahasa arab (studi pelatihan bahasa arab bagi tunanetra di wiyataguna bandung" menawarkan teknik peningkatan kemampuan (kompetensi) dalam menyerap materi yang sesuai dengan kemampuan tunanetra baik secara audiolingual, komunikatif, respon fisik, dan kooperatif disesuaikan dengan kondisi dilapangan. Kemampuan pembelajaran tunanetra tidak terfokus pada ketrampilan mendengar semata namun kemampuan membaca. Dimana hal itu sesuai dengan konsep yang mengatakan bahwa secara alamiah, proses pembelajaran pertama kali manusia adalah melalui pendengaran. ${ }^{62}$ Tentu hal tersebut bertolak belakang pendapat Orin Cornet bahwa gabungan gerakan alamiah bibir pada saat berbicara adalah proses pembelajaran awal manusia, isyarat-isyarat bahasa lisan jadi lebih tampak. Dimana hal tersebut sesuai dengan disabilitas (tunarungu) yang memiliki keterbatasan dalam mendengar. ${ }^{63}$

Penelitian lain adalah penelitian Audrey dalam "Management Competence for Service Marketing", menjelaskan untuk mencapai kinerja yang baik maka diperlukan secara efektif suatu kemampuan untuk pengembangan

58 Edy Suryo, "Visual Thinking dalam Memaksimalkan Pembelajaran Matematika Siswa Dapat Membangun Karakter Bangsa","http: //Jurnal. Upi .Edu/ File/Edi S.Pdf, Diunduh 18 Oktober 2018, h. 1-7."

${ }^{59}$ Ellys Ervyani, Meyta Pritandhari "Effcts Of Learning Styles Critical Thinking Ability Of Subjects In Economy Class X Semester Kartikatama Metra High School Academic Year". Jurnal Pendidikan Ekonomi, Vol.5, No.2, 2017, h. 21- 40.

${ }^{60}$ Nurotun Mumtahanah, "Penggunaan Media Visual dalam Pembelajaran PAI", Al Hikmah, Jurnal Studi Keislaman, Vol. 4. No. 1, 2004, h. 92-104.

${ }^{61}$ Ridwan Effendi, "Metode Pembelajaran Bahasa Arab (Studi Pelatihan Bahasa Arab Bagi Tunanetra di Wiyataguna Bandung", Disertasi Pascasarjana UIN Syarif Hidayatullah Jakarta, 2017.

62 Acep Hermawan, Metodologi Pembelajaran Pembelajaran Bahasa Arab, (Bandung: PT. Remaja Rosdakarya, 2011), h. 130-131.

${ }^{63}$ PSIBK USD Yogyakarta, Metode Pengajaran Bahasa bagi Anak Tunarungu, Dinas Pendidikan Luar biasa Propinsi Jawa Barat, di akses pada 19 Pebruari 2018. 
ilmu pengetahuan dan ketrampilan. ${ }^{64}$ Akan tetapi menurut Galloway, bahwa terdapat persamaan hak antara siswa dan guru, dimana tidak selalu siswa yang belajar, guru juga dapat belajar kepada siswa. ${ }^{65}$ Berbeda pada penelitian Akbari, dalam penelitiannya model pembelajaran yang selama ini hanya menjadikan peserta didik sebagai objek yang menerima informasi, dan selanjutnya untuk mengingat serta mengulang, belum sampai tahap menciptakan kesamaan hak antara siswa dan guru dalam satu proses belajar mengajar. ${ }^{66}$

Perbedaan penelitian ini dengan penelitian Ridwan Efendi adalah subyek siswa dan metode pembelajaran. Ridwan menggunakan subyek tunanetra dengan metode pembelajaran bahasa arab. Sedangkan penelitian ini subyeknya adalah tunarungu dan metode pembelajaran yang digunakan adalah metode visual thinking. Persamaan keduanya yaitu penekanan kompetensi yang dihasilkan. ${ }^{67}$

Bagus Cakraningrat dan Fuadah Fakhruddiana"6, "Kesiapan belajar siswa tunarungu yang memenuhi pendidikan inklusi". Penelitian ini menjelaskan adanya keterkaitan kondisi subyek berupa perhatian, bimbingan, kasih sayang dan semangat orangtua, sekolah serta teman sebaya. Sehingga terbentuk respon positif dari subyek. Hal tersebut di atas senada dengan penelitian Erika Nur Rohmatin, ${ }^{69}$ bahwa kesiapan belajar sebagai langkah awal pembelajaran siswa tunagrahita. Dimana kemampuan siswa tunagrahita dalam memusatkan perhatian, mengikuti pelajaran dari awal sampai akhir, mau mengerjakan tugas, memberi kecendrungan menjadi baik.

Menurut Lori rice-spearman, kesiapan belajar memberi pengaruh pada kemampuan mengikuti pembelajaran dengan baik juga kemampuan mengembangkan kecakapan yang dimiliki, menuju ke arah pengambilan tanggung jawab. ${ }^{70}$ Pada penelitian Bagus Cakraningrat dan Fuadah Fakhruddiana menjelaskan tentang kesiapan belajar. Sedang penelitian ini

${ }^{64}$ Audrey Gilmoreand, David Carson, "Management Competence for Service Marketing”, The journal of Servise Marketing, Vol. 10, No. 3, 2016, h. 39-57.

65 Sarah Galloway, "Reconsidering Emancipatory Education Staging A Conservation Between Paulo Freire and Jacques Rancere", Educational Theory, Vol. 62, No. 2, 2012, h. 163.

${ }^{66}$ Mohammad Ali Akbari and Elham Faraji, "Basic Principle of Critical Pedagogy", International Conference on Humanities, Historical and Social Science, Vol. 34, No. 4, 2011, h. 77.

${ }^{67}$ Ridwan Effendi, "Metode Pembelajaran Bahasa Arab (Studi Pelatihan Bahasa Arab Bagi Tunanetra di Wiyataguna Bandung", Disertasi Pascasarjana UIN Syarif Hidayatullah Jakarta, 2017.

68 Bagus Cakraningrat, Fuadah Fakhruddiana, "Kesiapan Belajar Siswa Tunarungu Yang Memenuhi Pendidikan Inklusi", Humanitas, Vol. 2, No. 2, 2015, h. $73-81$.

${ }^{69}$ Erika Nur Rohmatin, "Hubungan Kesiapan Belajar dengan Prestasi Belajar Matematika Pada Anak Tunagrahita Ringan", Jurnal Pendidikan Khusus, Vol. 1, No. 1, 2016, h. 1-11.

${ }^{70}$ Rice Spearman. L, "Self-Directed Learning Readiness in Clinical Laboratory Scientists: Developing Skill for Practice." Disertasi Texas Texh University, 2010, h. 11. 
menekankan pada metode pembelajaran yaitu visual thinking. Kedua penelitian ini sama-sama dilakukan pada sekolah inklusi, hanya saja pada penelitian ini, lebih difokuskan pada siswa tunarungu.

Mayasari ${ }^{71}$ dalam penelitiannya tentang $\mathrm{ABK}$ menyatakan bahwa strategi dalam implementasi sebuah kurikulum harus memperhatikan dan mengadaptasi keadaan siswa. Artinya siswa dapat menentukan tema yang akan dipelajari hari itu, hal tersebut dimaksudkan untuk menciptakan lingkungan pembelajaran komunikatif, ramah dan bersahabat.

Pada penelitian Mayasari dan penelitian ini memiliki kesamaan yaitu pada pembahasan kurikulum 2013 pada sekolah inklusi. Namun di penelitian Mayasari fokus pada penerapan kurikulumnya. Subyek dilakukan pada semua siswa berkebutuhan khusus. Sedangkan pada penelitian ini pada metode pembelajarannya yaitu metode visual thinking. Adapun subyek adalah siswa tunarungu.

Khoirul Huda ${ }^{72}$ dalam kajian anacusis (penderita tunarungu) pada pembelajaran bahasa Inggris menyatakan bahwa proses perkembangan dalam pelajaran bahasa asing bagi anacusis, khususnya lisan sedikit sulit, karena sistem linguistik bahasa Indonesia sama sekali berbeda dengan bahasa Inggris. Hal tersebut memberi fakta bahwa anacusis tidak dapat menerima input langsung dalam sistem bahasa ketunarungu yang seharusnya mereka kuasai, bukan karena kurangnya kemampuan kapasitas IQ.

Pendapat Khoirul Huda berbeda dengan Tati, yang menyatakan bahwa penglihatan anacusis sangat berperan meningkatkan kemampuan membaca (Bahasa reseptif visual) dan menulis (Bahasa ekspresif visual). Karena siswa tunarungu belajar dengan menghubungkan pengalaman yang diperolehnya dengan gerak bibir dan mimik dari pembicara. Hal tersebut untuk memahami hubungan antara lambang bahasa (visual dan auditori) dengan suatu benda, sama halnya seperti anak mendengar. ${ }^{73}$ Maka proses pembelajaran dianggap lebih efektif manakala visualisasinya dilakukan dengan lebih realitis, serupa dengan keadaan yang sesungguhnya. Dengan demikian, materi yang disampaikan akan dapat lebih mudah dipahami dan mampu memberikan peningkatan kualitas capaian prestasi peserta didik. ${ }^{74}$

${ }^{71}$ Mayasari, “Implementasi Kurikulum 2013 pada Anak berkebutuhan Khusus (ABK): Studi kasus SD Muhammadiyah Sapen, Yogyakarta”, Inklusi: Journal of Disability Studies, Vol. 3, No. 1, 2016, h. 1-18.

${ }^{72}$ Khoirul Huda, "Kajian Anacusis (Penderita Tunarungu) pada Pembelajaran dalam Perolehan Bahasa Inggris sebagai Bahasa Asing”, Jurnal Pentas, Vol. 3, No. 1, 2017, h. 1-15.

${ }^{73}$ Tati Hernawati, "Pengembangan Kemampuan Berbahasa dan Berbicara Anak Tunarungu", JASSI, Vol. 7, No. 1, 2007, h.101-110.

${ }^{74} \mathrm{Ni}$ Nyoman Suwastarini, Nyoman Dantes dan I Made Candiasa, "Pengaruh Implementasi Pembelajaran Berbasis Media Teknologi Informasi dan Komunikasi Terhadap Motivasi dan Hasil Belajar Matematika Siswa SDLB B (Tunarungu) pada SLB B Negeri PTN Jimbaran", Jurnal Program Pascasarjana Universitas Pendidikan Ganesha Program Studi Penelitian dan Evaluasi Pendidikan, Vol. 5, No. 1, 2015, h. 110 
Maka menurut Farida Zuniar, Muhamad Chamdani, bahwa kualitas pembelajaran bukan hanya terletak pada kurikulum yang baru, ketersediaan fasilitas, dan karakter pendidiknya. Melainkan juga guru harus bisa mengelola kelas dengan baik. Dimana guru harus mampu mengenal dan memahami potensi anak didik, mampu menerapkan strategi yang sesuai dengan karakteristik masing-masing siswa. Hal itu untuk melihat daya serap siswa, sehingga kualitas pembelajaran di kelas akan meningkat. ${ }^{75}$ Sejalan dengan penelitian ini, menurut Lenayanti, menjadi perhatian adalah pengembangan kompetensi guru dalam proses penyusunan program sekolah, strategi pengembangan siswa serta faktor pendukung dan penghambat proses belajar mengajar. ${ }^{76}$

Penelitian ini memiliki sisi yang mengisi kekurangan pada penelitian sebelumnya. Fokus riset ini adalah menjawab diskursus tentang apakah metode yang menentukan pelaksanaan pembelajaran bagi siswa dibanding materi. Atau apakah materi lebih menentukan dibanding metode pembelajaran bagi siswa inklusi. Penelitian ini ingin menjawab hak asasi manusia, model sosial, ${ }^{77}$ prinsip education for all. ${ }^{78}$ dan juga makna belajar menurut Al-Ghazali sebagai proses memanusiakan manusia, ${ }^{79}$ pada kelas inklusi.

Penelitian ini juga menjawab berbagai komponen pembelajaran seperti tujuan, rencana pelaksanaan pengajaran, penyampaian materi, metode, media dan evaluasi pada kelas inklusi. Adapun fokus pembelajarannya adalah pendidikan agama Islam. Penelitian ini memberi pendapat outcame ditinjau dari kompetensi siswa. Sehingga dapat memberikan sumbangsih bagi pendidikan.

\section{F. Metode Penelitian}

\section{Jenis Penelitian}

Penelitian ini bertujuan sebagai langkah pengembangan metode pembelajaran sekolah inklusi. Penelitian kualitatif ini adalah penelitian dasar (basic research) untuk menganalisis asas dalam ilmu pendidikan, sehingga

75 Farida Zuniar, Muhamad Chamdani, Inovasi Pendidikan Bunga Rampai Kajian Pendidikan Karakter, Literasi, dan Kompetensi Pendidikan dalam Menghadapi Abad 21, (Jakarta: Universitas Sebelas Maret, 2018), h. 354-362.

${ }^{76}$ Lenayanti Br. Pulungan, Yusrizal, Niswanto, "Pengembangan kompetensi profesional guru program khusus pada SDLB Negeri Banda Aceh", Jurnal Magister Administrasi Pendidikan Pascasarjana Universitas Syiah Kuala, Vol. 5, No. 3, 2017, h. $184-191$.

77 Bagus Cakraningrat dan Fuadah Fakhruddiana, "Kesiapan Belajar Siswa Tunarungu Yang Memenuhi Pendidikan Inklusi”, Humanitas, Vol. 2, No. 2, 2015, h. $73-81$.

${ }^{78}$ Dieni Laylatul Zakia, Guru Pembimbing Khusus (GPK): Pilar Pendidikan Inklusi, (Surakarta: Prosiding Seminar Nasional Pendidikan, 2016).

${ }^{79}$ Solichin, "Belajar dan Mengajar dalam Pemandangan Al Ghozali", Jurnal Tadris, Vol. 1 No. 1, 2006, h. 139-153. 
penelitian ini tidak secara langsung bermanfaat secara praktik namun butuh waktu untuk melihat hasilnya. ${ }^{80}$

Untuk memperoleh data secara menyeluruh memerlukan waktu, tenaga dan persiapan karena objek dan cakupan penelitian yang luas. Peneliti hanya mengambil kasus di salah satu sekolah inklusi sebagai objek yaitu metode pembelajaran di SMAN 54 Jakarta Timur. Sesuai data yang diperoleh, maka peneliti menggunakan metode deskriptif. Metode deskriptif merupakan metode yang dirancang untuk mengumpulkan informasi tentang keadaan nyata (yang sedang berlangsung). ${ }^{81}$

\section{Pendekatan Penelitian}

Penelitian basic research ini dengan menggunakan pendekatan filosofis post positivisme, digunakan untuk meneliti pada kondisi objek yang alamiah. Dengan indikator antara lain tidak adanya perbedaan siswa difabel dengan siswa pada umumnya, kecacatan sebagai hal yang alami yang tumbuh di masyarakat, adanya terjadi interaksi positif dalam gerak budaya manusia, pendidikan agama Islam merupakan usaha manusia dalam memahami alam semesta melalui pengamatan yang tepat (correct) pada sasaran, menggunakan prosedur yang benar (true) dan dijelaskan dengan penalaran yang sahih (valid) dapat menghasilkan kesimpulan yang betul (truth), metode itu menjadi titik temu proses pembelajaran.

Dan pendekatan humanistik belajar yang lebih cenderung pada proses dibandingkan dengan keluaran (output) akhir sesuai dengan gejala yang ditemukan. ${ }^{82}$ Dengan indikator antara lain bahwa proses belajar lebih penting dibandingkan dengan hasil akhir, bahwa belajar berfokus pada potensi manusia untuk pengembangan kemampuan, proses imagining harus ditujukan untuk kepentingan memanusiakan manusia, dimana guru hanya sebagai fasilitator dalam diskusi untuk pengembangan siswa, pendidikan agana Islam diharapkan mampu melakukan proses pembinaan nilai-nilai agama dalam membentuk kepribadian siswa, bahwa sensifitas guru dalam menentukan metode harus memahami karakteristik dan kebutuhan siswa inklusi.

\section{Sumber Data} sekunder.

Sumber data dalam penelitian ini terdiri dari data primer dan data

\section{a. Sumber Data Primer}

Sumber data primer diperoleh dari situasi yang terjadi di lingkungan sekolah baik dari pimpinan sekolah, guru pendidikan agama Islam, siswa

${ }^{80}$ Noor Muhammad Aziz, "Urgensi Penelitian dan Pengkajian Hukum dalam Pembentukan Peraturan Perundang-undangan", Jurnal Rechtsvinding, Vol. 1, No. 1, 2012, h. 17-32.

${ }^{81}$ Travers and Gay, Pengantar Metode Penelitian, (Jakarta: UI-Press, 2006), h. 71.

${ }^{82}$ Akif Khilmiyah, Metode Penelitian Kualitatif, (Yogyakarta: Samudra Biru, 2016), h. vii. 
tunarungu, siswa sekelas, koordinator siswa berkebutuhan khusus, kepala bidang kurikulum, kepala bidang kesiswaan, guru kelas, orangtua siswa tunarungu. Kemudian sumber utama dari panduan profil SMAN 54, perangkat pembelajaran pendidikan agama Islam semester genap

\section{b. Sumber Data sekunder}

Sumber riset ini diperoleh dari jurnal-jurnal, buku, makalah, artikel, berita yang berkaitan dengan pendidikan inklusi, siswa tunarungu, visual thinking, antara lain:

Pertama, yang berhubungan dengan visual thinking antara lain; Decoding Visual Thinking, ${ }^{83}$ Seeing, Thinking and knowing,${ }^{84}$ A. Historical Sociology of childhood, ${ }^{85}$ Critical Thinking Skills for Education Students, ${ }^{86}$ Thinking and Seeing, Visual metacognition in Adults and Children, ${ }^{87}$ Visual thinking in Mathematics. ${ }^{8}$

Kedua, yang berhubungan dengan Siswa Berkebutuhan Khusus antara lain; Black a model for deep educational students succes, ${ }^{89}$ Pendidikan dan Bimbingan Anak Berkebutuhan Khusus, ${ }^{90}$ Pendidikan Inklusi untuk ABK, ${ }^{91}$ Pembelajaran yang Ramah, ${ }^{92}$ Mengenal Pendidikan

${ }^{83}$ Bolton, S. Decoding Visual Thinking. Paper presented at Naver Workshop Visualizing Creative Strategies, Rio de Janeiro: Esdi. 2011, diakses 18 Pebruari 2020.

84 Arturo carsetti, Seeing, Thinking and Knowing: meaning and selforganisation in visual cognition and thought, (Italy: Kluwer Academic Publishers, 2004), h. 1-361.

85 Andre Turmel, A. Historical Sociology of Childhood, Developmental Thinking, Categorization and Graphic Visualization, (New York: Cambridge university press, 2008), h. 1-376.

${ }^{86}$ Brenda Judge, Patrick Jones and Elaine McCreery, Critical Thinking Skills for Education Students, (British: Learning matters 1td, 2009), h. 1-65.

${ }^{87}$ Daniel T. Levin, Thinking and Seeing, Visual Metacognition in Adults and Children, (England: The MIT press Combridge, 2004), h. 1-303.

88 Marcus Ciaquinto, Visual Thinking in Mathematics, an Epistemological Study, (New York: Oxford universitypress, 2007), h. 1-298.

${ }^{89}$ Carolyn. E. Willromsum, Blak a Model for Deep Educational Student Succes, (USA: Gallawdet university press, 2007), h. 1-228.

${ }^{72}$ JatiRinakriAtmaja, Pendidikan dan Bimbingan Anak Berkebutuhan Khusus, (Bandung: Remaja Rosdakarya, 2008), h. 1-316.

73 Stella Olivia, Pendidikan Inklusi untuk Anak Berkebutuhan Khusus (Diintegrasikan Belajar di SekolahUmum), (Yogyakarta: Andi press, 2017), h. 1-80.

74 Dedy Kustawan, Pembelajaran yang Ramah (Merancang Pembelajaran Aktif, Inovatif, Efektif dan Menyenangkan di Sekolah Ramah Anak), (Jakarta: Luxima, 2016), h. 1-129. 